\title{
Habitat Conditions and Distribution Pattern of the Gutless Oligochaete Phallodrilus leukodermatus
}

\author{
Olav Giere ${ }^{1}$, Gerd Liebezeit ${ }^{2}$, Rodger Dawson ${ }^{2}$ \\ ${ }^{1}$ Zoologisches Institut und Museum, Universität Hamburg, Martin-Luther-King-Platz 3, D-2000 Hamburg 13, \\ Federal Republic of Germany \\ ${ }^{2}$ Sonderforschungsbereich 95, Universität Kiel, Olshausen-Straße 40/60, D-2300 Kiel 1, Federal Republic of Germany
}

\begin{abstract}
ABSRACT: Analysis of pore water and sediment for a number of physical and chemical parameters in carbonate sand cores from Bermuda, populated by the gutless oligochaete Phallodrilus leukodermatus, revealed that the worms are well supplied with dissolved nutrients originating primarily from intensive (bacterial) degradation of algal debris. On average, free amino acids ranged from 30 to $80 \mu \mathrm{mol} \mathrm{dm}^{-3}$ pore water; total carbohydrates, from 4,000 to $7,000 \mu \mathrm{g} \mathrm{dm}^{-3}$; and dissolved organic carbon from ca. 20 to $30 \mu \mathrm{g} \mathrm{dm}^{-3}$. The sediments at or below the redox discontinuity layer, which usually contained the highest concentrations, harboured the richest populations of the tubificids (maximum densities about 85,000 ind $\mathrm{m}^{-2}$ ). This distribution pattern of gutless worms in relation to their ambient interstitial environment infers that these animals, which always associate with subcuticular bacteria, live preferably in oligoxic or anoxic sediments, rich in nutrients and hydrogen sulphide. Such adaptation compares well with that of other gutless animals recently investigated.
\end{abstract}

\section{INTRODUCTION}

Following a description of morphological and ultrastructural details in the aberrant marine oligochaete Phallodrilus leukodermatus (Giere, 1979, 1981), its ecology and peculiar mode of nutrition remained to be investigated. While in pertinent studies of other annelids (e.g. Stephens, 1975; Jørgensen, 1979; Jørgensen and Kristensen, 1980a, b) discussions arose pertaining to the actual pathways and quantities of incorporated dissolved organic matter in relation to 'normal', oral ingestion, in $P$. leukodermatus transepidermal uptake of nutrients would appear to be obligatory owing to the absence of mouth and gut. Thus, ecological work on this annelid somewhat reflects the debated 'pogonophoran situation'; however, the small, tubeless Clitellata are more suitable for ecological studies because of their locally rich occurrence in the interstitium of shallow bottoms. The present results describing the distributional pattern of these tubificid worms in subtidal carbonate sands of Bermuda in relation to ambient environmental parameters, are part of a current research project on the structure and ecophysiology of gutless Oligochaeta with results of experiments on uptake of dissolved nutrients to follow.

\section{MATERIAL AND METHODS}

Quantitative samples were taken by SCUBA diving at ca. $4 \mathrm{~m}$ water depth at Flatts Inlet, a narrow passage to Harrington Sound, Bermuda (for topographical details see Morris et al., 1977). Perspex corers (internal diameter $5 \mathrm{~cm}$ ) were pushed into the sediment to retrieve fauna and sand down to a depth of $30 \mathrm{~cm}$. The core was immediately subdivided, usually into $5-\mathrm{cm}$ layers (in some cases $2.5-\mathrm{cm}$ layers) for subsequent quantitative extraction of oligochaetes and other meiofauna by a modified version of the Ludox AMflotation method (Nichols, 1979) and for sediment analysis (grain size, water content). Interstitial water at fixed sampling depths was obtained in situ in the direct vicinity of the sediment core, employing a lance equipped with $35 \mathrm{~cm}^{3}$ disposable syringes connected by Teflon capillaries to prefilter gauzes (mesh size 200 $\mu \mathrm{m}$ ). The advantage of this device for obtaining pore water, compared to high-pressure-squeezing of sediment core fractions, was discussed by Liebezeit (1980). In order to protect the uppermost sediment layers from artificial erosion by shock waves, the sampler was driven into the relatively compact sand (water content only ca. $15 \%$ weight) through a 1-m diameter PVC shield placed on the surface of the sampling site. 
The interstitial water from the different sediment horizons (2 $\mathrm{cm}$ to $4 \mathrm{~cm}$ intervals), tightly enclosed in the respective syringes, was analyzed immediately after return to the laboratory for the following parameters (concentrations always refer to $\mathrm{dm}^{3}$ pore water):

- Redox potential, determined with specially designed, pointed Pt-electrodes;

- hydrogen sulphide $\left(\mathrm{H}_{2} \mathrm{~S}\right)$, measured colorimetrically as described by Fonselius (1976), but modified as a micromethod (Dawson and Liebezeit, in prep.);

- phosphate, ammonia, urea, analyzed according to methods described in Grasshoff (1976) and Liebezeit (1980) in a modified micromethod (Dawson and Liebezeit, in prep.);

- carbohydrates, monomers (MCHO), polymers ( $\mathrm{PCHO}$ ) and total ( $\mathrm{TCHO}$ ), recorded from $\mathrm{GF} / \mathrm{C}$ filtered water (filters $0.8 \mu \mathrm{m}$, precombusted) following the methods of Burney and Sieburth (1977) and Johnson and Sieburth (1977) (for filter method see remarks in Discussion);

- dissolved free amino acids (DFAA) from samples stored at $-20^{\circ} \mathrm{C}$ (Jørgensen et al., 1981), identified after HPLC-separation (Lindroth and Mopper, 1979) with the modifications suggested by Liebezeit and Dawson (1981);

- dissolved organic carbon (DOC), determined according to Schreurs (1978) after filtration through precombusted GF/C-filters $(0.8 \mu \mathrm{m})$ (for filter method see remarks in Discussion).

All techniques were carefully calibrated prior to the start of the sampling programme; linearity and reproducibility of the techniques applied were found to be within generally accepted limits. Parallel calibration standards were run with each set of samples. Chemical recordings, particularly the differentiated analyses of amino acids, will be dealt with in detail elsewhere; they are reported here only as background data for interpretation of ecological conditions. Data in Figs. 2 and 3 are characteristic sets selected as representative illustration of the chemical environment of the worms. Discrepancies in sampling depths between sediment cores and pore water sampler prevented direct statistical correlating of habitat conditions and tubificid distribution pattern.

\section{RESULTS}

\section{Hydrography and Sedimentology}

The hydrography of the investigation area is characterized by very strong tidal currents (averaged maximum velocity $1.7 \mathrm{~m} \mathrm{~s}^{-1}$; Morris et al,, 1977). Periodically, these supply Flatts Inlet with Harrington Soundwater, usually somewhat richer in nutrients than the corresponding influx from the open sea (Morris et al., 1977; Balzer and Keller, 1978).

Despite such exposition the sediment proved to be very little sorted medium sand (sorting coefficient ca. 2.2 inedian values 180 to $240 \mu \mathrm{m}$ ) with the fractions 125 to $250 \mu \mathrm{m}$ and 250 to $500 \mu \mathrm{m}$ almost uniformly accounting for 50 to $65 \%$, but with the coarser fractions (500 to $1,000 \mu \mathrm{m}$ and 1,000 to $2,000 \mu \mathrm{m})$ also well represented (10 to $20 \%$ each). Only very fine $(<125$ $\mu \mathrm{m})$ and coarse $(>2.000 \mu \mathrm{m})$ particles were rare. This same substrate structure was recorded throughout the sediment column with little tendency towards coarse fractionation at the surface. Cores along a transect across the inlet showed sediment closer to the shores to be slightly finer than that in the middle of the tidal channel. The sediment consisted of calcareous fragments of mollusc shells and coral skeletons, large foraminiferan shells, pieces of sea urchin spines, coralline algae together with fragments of Cladophora sp. The elements were clearly recognisable in the coarser fractions $(>500 \mu \mathrm{m}$ ); in the finer fractions (between 63 and $500 \mu \mathrm{m})$, the portion of unidentifiable, triturated carbonate substances increased steadily. The het erogeneous grain size distribution with a deficit of the finer fractions $(<125 \mu \mathrm{m})$ indicates that the carbonate particles are subject to continuous abrasion and tidal flushing.

Wide areas of the bottom were covered with mats of the red algae Centroceras clavulatum and Ceramium cruciatum, growing in dense, irregular patches with areas of bare sand mainly in the middle reaches. Resulting from particle abrasion and trituration of algal material, the voids in the sediment were often filled with fine, flocculent debris which reduced the water permeability in the sediment column considerably.

\section{Physical and Chemical Characteristics}

Intensive biological and chemical decomposition of organic matter (water temperatures ca. 28 to $30^{\circ} \mathrm{C}$ ) in the sediment depletes the oxygen and produces a marked redoxpotential discontinuity (RPD) layer developed already at a depth of $7 \mathrm{~cm}$ (Fig. 1) with highly reducing sediments below (often ca. $-250 \mathrm{mV}$ to $-300 \mathrm{mV}$; Figs. 2 and 3) rich in hydrogen sulphide (up to $32 \mu \mathrm{mol} \mathrm{dm}^{-3}$; Fig. 3). In the lateral parts of Flatts Inlet with their finer sediments and dense algal mats, anoxia with $\mathrm{H}_{2} \mathrm{~S}$ formation was recorded in the very surface horizons. Consequently, despite a substantial proportion of coarse particles and their high exposure to intensive currents in the water column, the physiographic situation in Flatts Inlet resembles more closely that of fine or muddy sands in sheltered areas. 
Interstitial pH- and salinity conditions, not monitored regularly nor reported here in detail, lay within the normal range for subtropical, fully marine areas with carbonate sediments (e.g. Morris et al., 1977) without exhibiting major fluctuations. Apparently they do not affect the distribution of Phallodrilus leukodermatus (Giere, 1977). Salinity (measured refractometrically) was ca. $36 \% \mathrm{~S}, \mathrm{pH}$-values (recorded electrometrically) were 7.8 to 8.2 , decreasing somewhat within the anoxic layers.

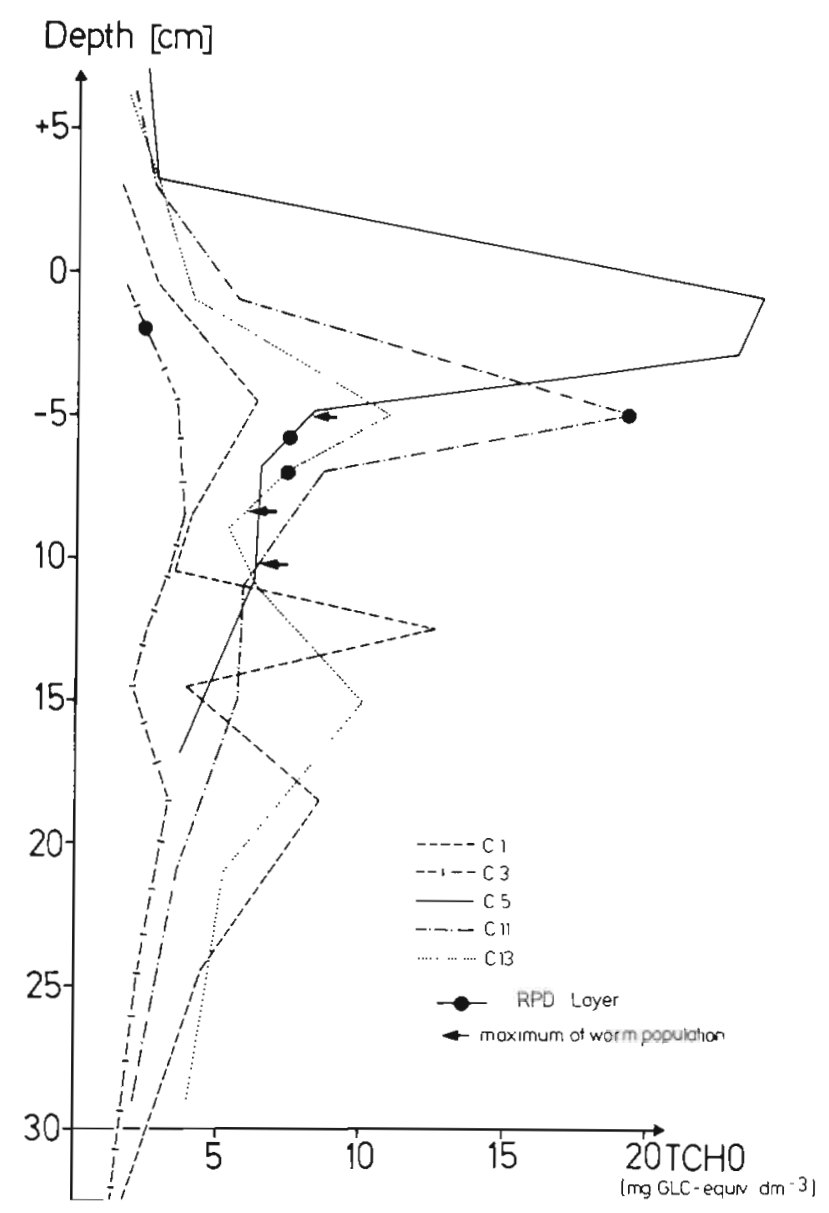

Fig. 1. Distribution of total cabohydrates ( $\mathrm{TCHO}$ ) in relation to Phallodrilus leukodermatus population maxima and positions of the redox potential discontinuity (RPD) layer in vertical cores

Extensive decomposition of particulate organic matter in the sediment is signified by the high values for carbohydrates (both mono- and polymers; in Figs. 1 to 3 combined as total carbohydrates', TCHO), originating mainly from the breakdown of algal debris. The compounds concentrate predominantly near or slightly below the RPD layer (Fig. 1), with the exception of Core 5 (see below). Although there was no clear pattern of carbohydrate composition within the vertical cores, on average a slight preponderance of the polymers was discernible. The generally much lower TCHO values in the overlying water relative to the concentrations in the pore water (Figs. 1 to 3) demonstrate the high retention capacity of the interstitial system (see Discussion).

The wide fluctuations in TCHO values are usually paralleled by variations in the content of dissolved organic carbon (DOC), although this fraction includes other carbon sources than sugars. This becomes particularly evident in the water overlying the bottom where a marked decrease of DOC values does not correspond to a noticeable decrease in TCHO. The high values for dissolved free amino acids (DFAA), intermediate products in the degradation of proteins, further indicate considerable chemical and bacterial activity in the sediment (Fig. 3). The DFAA-spectra in the various cores, dominated up to 50 mole \% by glutamic acid with $\beta$-glutaric acid and glutamine as additional major components, resembled each other fairly closely. A relatively uniform qualitative pattern was also evident in samples from the different sediment layers. On the other hand, the steep decline of total DFAA towards the surface and particularly in the supernatant water suggests an enhanced consumption and dissipation in the open water compared to the more conservative milieu of supply and removal in the sediment. Even the unusually high concentrations at 1 $\mathrm{cm}$ depth in Core 5 (Fig. 3; corresponding data from other cores are one order of magnitude lower) almost completely disappeared in the near-bottom water $4 \mathrm{~cm}$ above.

In Core 5 (Fig. 3) the curves for DOC and carbohydrates show a large maximum parallel to that of DFAA in the uppermost sediment layers. A coinciding peak for urea supports the inference that domestic sewage outlets in the vicinity influence the abiotic milieu of this irregular core. For comparison with the situation in Flatts Inlet, the interstitial milieu from a core with similar sediments in the outer reef fringe of the Bermudas (North Rock) has been studied. (Here, Phallodrilus leukodermatus and another gutless tubificid, $P$. planus were also found, although in fewer numbers.) In the relatively coarse sediment (mainly 500 to $2,000 \mu \mathrm{m}$ ) the clearly positive redox conditions (between +150 and $+180 \mathrm{mV}$ ) and the complete lack of hydrogen sulphide throughout the whole sediment column sampled ( $>20 \mathrm{~cm}$ depth) represent a contrasting difference to the biotope in Flatts Inlet. While contents in carbohydrates (both monomeric and polymeric), urea and phosphate fluctuated in the same range as in the main sampling area, values for ammonia were markedly lower in the coral reef sand. All chemical parameters showed maxima in 5 to $7 \mathrm{~cm}$ sediment depth except $\mathrm{NH}_{4}^{+}$, for which the highest values were measured in 


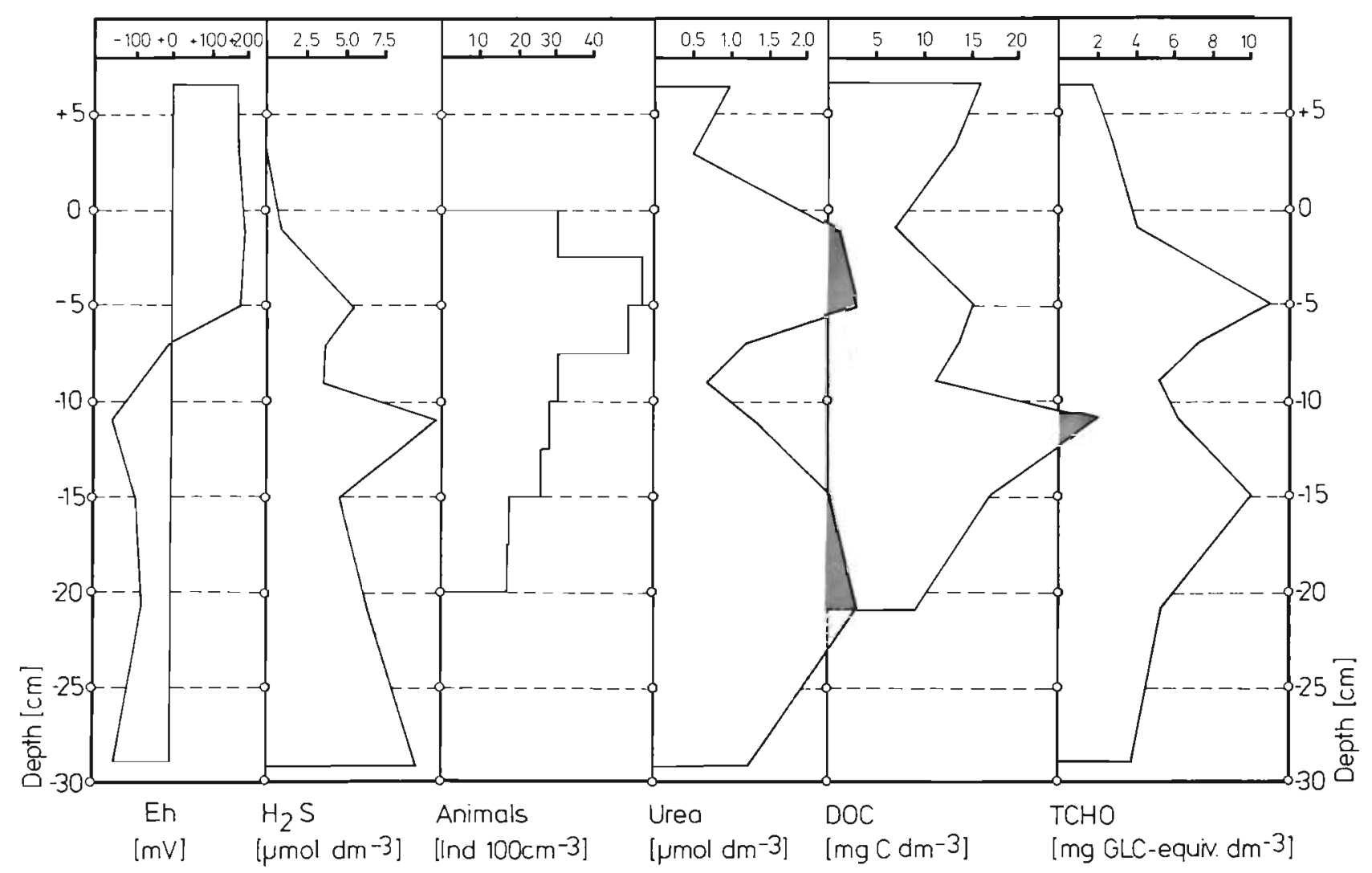

Fig. 2. Distribution pattern of physical and chemical parameters and occurrence of Phallodrilus leukodermatus in a selected vertical sand core (Core 13 )

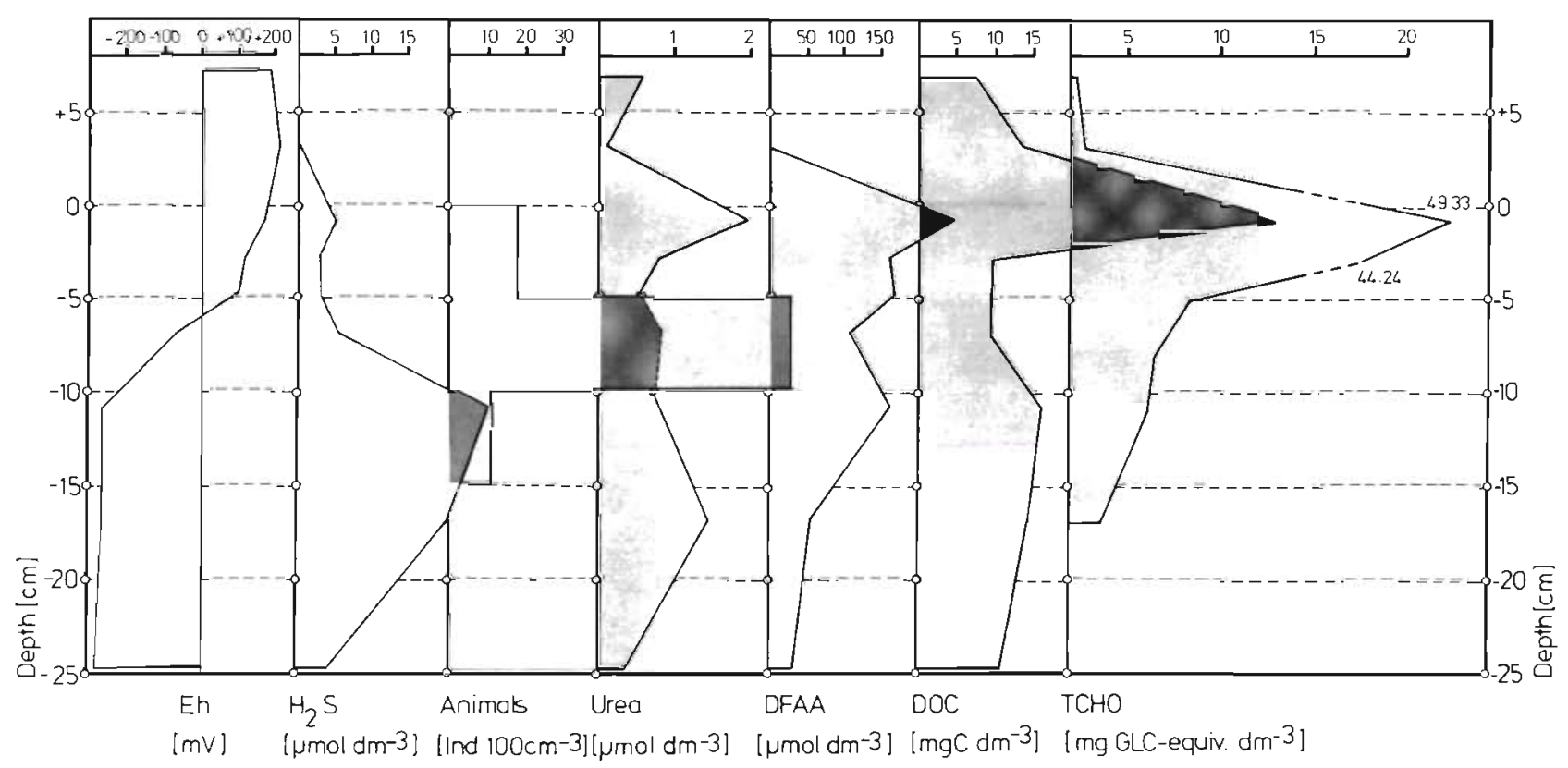

Fig. 3. Distribution pattern of physical and chemical parameters including amino acids and occurrence of Phallodrilus leukodermatus in a selected vertical sand core (Core 5) 
11 and $15 \mathrm{~cm}$ depth (DFAA concentrations were not recorded in this core).

\section{Occurrence of Phallodrilus leukodermatus}

While the gutless worms were only found in sparse numbers in the carbonate sand of the coral reefs around Bermuda (the species was described on the basis of only very few specimens; Giere, 1979) we found unusually rich populations in the sediments of Flatts Inlet. Judging from our cores, about 60,000 individuals $\mathrm{m}^{-2}$ seem to represent the average number here. Similar figures for the various sampling stations spaced across the width of the Flatts Inlet channel with a maximum of 84,000 worms $\mathrm{m}^{-2}$ suggest that these population densities are quite representative for the location and do not merely depict local aggregations.

The vertical distribution of Phallodrilus leukodermatus regularly exhibited a population maximum at 5 to $10 \mathrm{~cm}$ depth (Figs. 1 to 3 ), usually in the same stratum as the RPD layer or below it in anoxic sediments where the nutrient content was generally higher than in the surface layers. Only a slight decrease in population density with depth could be shown (Fig. 2). Active, apparently vigorous worms were often found in considerable numbers as deep as 20 or even $30 \mathrm{~cm}$ in layers completely devoid of oxygen.

All of the other abundant meiofauna in the uppermost oxic layers (particularly nematodes and harpacticoids, but also ostracods and other interstitial oligochaetes such as the enchytraeid Grania macrochaeta and unidentified tubificids) were absent in the lower $\mathrm{H}_{2} \mathrm{~S}$ layers.

However, the composition of Phallodrilus leukodermatus populations remained relatively homogeneous in all layers, with strikingly white individuals cooccurring with more transparent, 'pale' ones. These differences in appearance are probably due to ultrastructural changes in components of the worms' dermis (Giere, 1981). Fully mature adults, as well as juveniles of all sizes, were present in every core. However, juvenile worms appear to prefer the oxic surface strata above the RPD threshold where often 75 to $95 \%$ of the worms were immature. Similarly, the somewhat finer sediments from stations close to the shore usually contained more juveniles than those from the central channel. Despite quantitative evaluations of numerous samples, only very few oligochaete cocoons could be found; this infrequent occurrence could not conclusively be ascribed to $P$. leukodermatus. It may well be that this species is also aberrant in that it does not secrete a cocoon typical of most oligochaetes, but produces single, hardly discernible eggs. This would conform with its inconspicuous clitellar girdle.

\section{DISCUSSION}

The abundance and vertical distribution pattern recorded here for Phallodrilus leukodermatus, extraordinary both in relation to other gutless oligochaetes (Jamieson, 1977; Erséus, 1979), as well as to sublittoral populations of 'normal' marine oligochaetes (Giere and Pfannkuche, 1982), requires scrutinization of habitat conditions at Flatts Inlet and comparison with data from other areas.

Average values (usually 30 to $80 \mu \mathrm{mol} \mathrm{dm}^{-3}$ ) for DFAA, one of the most relevant organic compounds for transepidermal uptake (Stephens, 1975; Jørgensen, 1976; Tempel and Westheide, 1980) were mostly higher in the cores monitored here than in other eulittoral or sublittoral sediments. With the exception of a few peak values $\left(244 \mu \mathrm{mol} \mathrm{dm}^{-3}\right)$, they lay in the range for intertidal mud flats (Stephens, 1975; Costopulos et al., 1979; Jørgensen et al., 1980; Jørgensen et al., 1981), for sandy beaches (Tempel and Westheide, 1980), or for sublittoral areas (Henrichs and Farrington, 1979; Southward et al., 1979). The concentrations of DFAA found in Flatts Inlet exceeded by a factor of 2 to 3 corresponding data in other carbonate sediments from nearby Bermudian shores (Lyons et al., 1979; Liebezeit, 1980).

The position of the maximum concentrations around the RPD layer, together with the high proportions of $\beta$ glutaric acid, point to a zone of intensive bacterial activity (Jørgensen and Fenchel, 1974; Rhoads, 1974; Stephens, 1975; Jørgensen et al., 1980; Yingst and Rhoads, 1980; Jørgensen et al., 1981) degrading the plant debris from the dense mats of Cladophora and red algae in the surroundings (Morris et al., 1977; Liebezeit, 1980). The rich supply of $\mathrm{NH}_{4}^{+}$, an end product of amino acid degradation (Jørgensen et al., 1981) and still measureable in the oxic layers, emphasizes considerable bacterial activity. High concentrations of $\beta$-alanine and ornithine also document intensive decarboxylizing activities of sediment bacteria. The existence of these acids in the supernatant water clearly indicates a diffusion of organic nutrients from sand into water (Jørgensen et al., 1980). A significant upward flux of amino acids from anoxic depths to oxic upper sediments is also reflected by the homogeneous pattern of DFAA in the various layers, extending as a result of sediment flushing into the supernatant water. However, here, the concentration decrease reflects the strong dilution by currents and possibly also an enhanced uptake by bacteria (Jørgensen et al., 1980, 1981). Glutamic acid and aspartic acid, found in the pore water, may also represent extracellular products excreted directly by the algae (Jørgensen et al., 1980.)

The content of dissolved nutrients in Flatts Inlet sands is even more impressive if total carbohydrates 
(TCHO) are considered. Here, this pool - with glucose probably being an important component originating from bacterial degradation and autolysis of algae (Liebezeit, 1980; Mopper et al., 1980) - usually ranges an order of magnitude higher than in sediments of other seas (500 to $4,000 \mu \mathrm{g} \mathrm{dm}^{-3} \mathrm{MCHO}$ in Flatts Inlet; $285 \mu \mathrm{g} \mathrm{dm}^{-3}$ on eutrophicated German shores: MeyerReil et al., 1980). But also in comparison to nearby carbonate sands of similar structure, the bottom in Flatts Inlet is unique in that it contains carbohydrate concentrations often 10 times higher than other sites from Bermudian shallow-water sediments, including those in the neighbouring closed basin of Harrington Sound (Lyons et al., 1979; Liebezeit, 1980).

Parallel trends in the curves for sugars and dissolved organic carbon indicate that carbohydrates represent a considerable fraction in the pool of organic matter. As with the sugars, the higher values for DOC in the interstitial system, compared to the supernatant water, may result both from flushing and dilution effects above the sediment surface, and also from increased decomposition rates in the sand. Lyons et al. (1979) found a similar vertical pattern in other Bermuda bottoms; however, they - as well as Morris et al. (1977) and Liebezeit (1980) - recorded clearly lower values, even at sampling stations neighbouring Flatts Inlet. Only in a few reduced bottoms have DOC values of similar or higher ranges been recorded (see compilation in Farke and Riemann, 1980).

The possibility cannot be excluded that small microorganisms and colloidal mucus fibrils originating from bacteria (Farke and Riemann, 1980) pass the GF/C filters used here. Their contribution, however, is held to be fairly low considering the 'gentle' extraction method applied and the amount of carbon contained in these particles in relation to the high $\mathrm{DOC}$ data recorded (Meyer-Reil, pers, comm.). In the case of monosaccharides and free amino acids, the analytical techniques employed at near neutral $\mathrm{pH}$ would not estimate those components in particulate or colloidal matter (see discussion in Gocke et al., 1981).

The most striking observation concerning the occurrence of Phallodrilus leukodermatus, in addition to its high population density, is its vertical distribution: maximum numbers in oligoxic or anoxic sediments, where the worms are continuously exposed to hydrogen sulphide. Population decrease towards the oxygenated surface layers is apparently more abrupt than towards the anoxic depth (Fig. 2). Further studies are needed to determine whether this distributional pattern quite independent of oxygen conditions is related only to the concentration of nutrients which are usually higher in deeper horizons than near the surface. The preferred layers offer the advantage of shelter from grazing by large shoals of small fish common in Flatts
Inlet. Food competition by bacteria for dissolved nutrients is unlikely to be a major factor affecting the vertical distribution of the worms, since the highest numbers of microorganisms exist at or near the RPD layer (Yingst and Rhoads, 1980); even here, the concentrations of dissolved organics in our study area seem high enough to provide both bacteria and worms with ample food.

The vertical distribution of Phallodrilus leukodermatus is in contrast to that of all other marine oligochaetes investigated (Giere and Pfannkuche, 1981) and differs even from that of extremely euryoxybiontic species like Peloscolex benedeni whose vertical distribution could be correlated with positive Eh recordings despite its relatively high tolerance for anoxia (Pfannkuche, 1980).

Three possibilities have been proposed for coping with the problems of animal life in oligoxic or anoxic environments - rich in $\mathrm{H}_{2} \mathrm{~S}$, which is almost persistently the 'preferred' biome of anenteric animals:

(1) Large amounts of reserve substances (e.g. glycogen) are probably used for anaerobic respiration in polychaetes and in pogonophorans, such as Siboglinum atlanticum (Southward, 1973). In Phallodrilus leukodermatus, a thick 'mantle' of 'multivesiculate corpuscles' has been found underneath the cuticle (Giere, 1981), filled with numerous globules of as yet unidentified carbohydrates (Dr. K. S. Richards, pers. comm.). In EM sections, the typical glycogen rosettes could not be observed. These substances seem to be subject to physiological alterations in the worm since they are often different in their electron densities in sections from various worms (own unpubl. observ.). (2) If storage of reserves for temporary anaerobic respiration is combined with an extended blood vascular system capable of carrying high oxygen loads even under adverse oxic conditions - as in some mud-living tubificids (Schöttler and Schroff, 1976; Hoffmann, 1978 ) or in the vestimentiferan pogonophore Riftia from extremely hypoxic deep sea bottoms (Arp and Childress, 1981) - chances for a longer endurance in or underneath the RPD layer would be enhanced. In $P$. leukodermatus, the very wide blood vessels traversing the coelomic cavity, are an unusual anatomical feature, suitable for efficient oxygen transport (Giere, 1981). (3) An even more advanced evolutionary step towards life in anoxic depths is detoxification of $\mathrm{H}_{2} \mathrm{~S}$ by oxidation, as demonstrated in some interstitial animals from sands rich in hydrogen sulphide (Powell et al., 1979, 1980), and - beyond this stage - the utilization of chemical energy bound in $\mathrm{H}_{2} \mathrm{~S}$ for trophic metabolism through incorporation of chemo-autotrophic bacteria producing Calvin-Benson-cycle enzymes. This mode of direct $\mathrm{CO}_{2}$-fixation has been documented recently for some pogonophorans (Felbeck, 1981; Felbeck et al., 
1981; Southward et al., 1981) and suggested also for the gutless bivalve genus Solemya (Reid and Bernard, 1980). Underneath its cuticle $P$. leukodermatus always harbours numerous gram-negative bacteria (Giere, 1981) of similar size as in pogonophorans (Cavanaugh et al., 1981; Southward et al., 1981). They contain numerous granules some of which resemble carboxysomes', organelles rich in enzymes catalyzing the Calvin-cycle (own tentative observations). A similar situation may exist in P. albidus, a gutless oligochaete from Australian reefs which is also associated with subcuticular bacteria (Richards et al., 1982).

The habitats of all gutless animals described so far seem to be characterized by 'extraordinary energy sources' (Reid, 1980). As early as 1899, Stempell concluded for the bivalve Solenomya togata that reduction of the gut seems to be possible only in environments with a rich supply of organic substances. The present work shows that the sands of Flatts Inlet are among the benthic biotopes with the highest concentrations of dissolved organic matter. Although rapid turnover rates of these pools can be assumed in this environment, there are sufficient dissolved nutrients available to sustain populations of anenteric animals at densities considerably higher than known from the largest pogonophoran stocks of comparative individual size: 200 Siboglinum fiordicum $\mathrm{m}^{-2}$ (George, 1975, 1977) lived in pore water much poorer in amino acids and probably also carbohydrates (Southward et al., 1979) than the gutless oligochaetes in Flatts Inlet.

That even less specialized marine annelids with a gut can maintain a substantial transepidermal influx of amino acids into their body under adverse anoxic conditions and at ambient 'food' concentrations lower than recorded in our cores, was demonstrated by Siebers (1976), Siebers and Bulnheim (1977) and Costopulos et al. (1979).

Further studies are planned in order to ascertain whether Phallodrilus leukodermatus is able to live for extended periods, or even permanently, near or underneath the RPD treshold. It should be emphasized that this specialized annelid does not only survive passively in a reducing sediment strongly smelling of hydrogen sulphide, but was regularly observed to move actively in deep layers without any access to oxygen via tubes or burrows. This is in some contrast to arguments which stress that these structures are necessary for active life of 'higher' animals in anoxic habitats (Reise and Ax, 1979, 1980). An enclosure of some kind, capable of containing and confining sufficient solute concentrations was also believed to be indispensable for anenteric life (Reid, 1980), but this is lacking in gutless oligochaetes.

This infers that Phallodrilus leukodermatus and related tubificids from coralline sands (Erséus, 1979;
Giere, 1981; Richards et al., 1982) developed, parallel to a number of structural peculiarities, unusual ecological strategies which facilitate anenteric life, new to annelids. Further studies are intended to follow more closely these novel pathways which may turn out to be of general ecological significance.

Acknowledgements. We thank Mr. F. Bohde, Kiel, for assistance in evaluating the data and Mrs. M. Hänel, Hamburg, for drawing the figures. Our thanks go also to Dr. C. Erséus, Göteborg, for informing us about the rich occurrence of Phallodrilus leukodermatus in Flatts Inlet. We are grateful for financial support from the Deutsche Forschungsgemeinschaft (Gi 100/6-1) and for a grant-in-aid from the Bermuda Biological Station for Research.

Contribution No. 889, Bermuda Biological Station for Research, Bermuda; Report No. 390, Sonderforschungsbereich 95, Universität Kiel, Kiel, Federal Republic of Germany.

\section{LITERATURE CITED}

Arp, A. J., Childress, J. J. (1981). Blood function in the hydrothermal vent vestimentiferan tube worm. Science, $N$. Y. 213: 342-344

Balzer, W., Keller, I. (1978). Freisetzung von Nährstoffen. In: Wefer, G. Hempel, G. (eds.) Das Harrington Sound Projekt des SFB 95. Bericht über die dritte Meßphase (Aug.-Okt. 1978). Rep. SFB 95, Univ. Kiel 48: 14-18

Burney, C. M., Sieburth, J. McN. (1977). Dissolved carbohydrates in seawater. II, a spectrophotometric procedure for total carbohydrate analysis and polysaccharide estimation. Mar Chem. 5: 15-28

Cavanaugh, C. M., Gardiner, S. L., Jones, M. I., Jannasch, H. W., Waterbury, J. B. (1981). Prokaryotic cells in the hydrothermal vent tube worm Riftia pachyptila Jones: possible chemoautotrophic symbionts. Science, N. Y. 213: 340-342

Costopulos, J. J., Stephens, G. C., Wright, S. H. (1979). Uptake of amino acids by marine polychaetes under anoxic conditions. Biol. Bull. mar. biol. Lab., Woods Hole 157: 434-444

Erséus, C. (1979). Taxonomic revision of the marine genus Phallodrilus Pierantoni (Oligochaeta, Tubificidae), with descriptions of thirteen new species. Zool. Scripta 8: $187-208$

Farke, H., Riemann, F. (1980). Dissolved organic carbon in littoral sediments: concentrations and available amounts demonstrated by the percolation method. Veröff. Inst. Meeresforsch. Bremerhaven 18: 235-244

Felbeck, H. (1981). Chemoautotrophic potential of the hydrothermal vent tube worm, Riftia pachyptila Jones (Vestimentifera). Science, N. Y. 213: 336-338

Felbeck, H., Childress, J. J., Somero, G. N. (1981). CalvinBenson cycle and sulphide oxidation enzymes in animals from sulphide-rich habitats. Nature, Lond. 293: 291-293

Fonselius, S. K. (1976). Determination of hydrogen sulphide. In: Grasshoff, K. (ed.) Methods of seawater analysis. Verlag Chemie, Weinheim, pp. 71-78

George, J. D. (1975). Observations on the pogonophore, Siboglinum fjordicum WEBB from Fanafjorden, Norway. Rep. Underwater Ass. 1: 17-26

George, J. D. (1977). The pogonophore epidermis, its structure, functions and affinities. Symp. zool. Soc. Lond. 39: $195-222$ 
Giere, O. (1977). An ecophysiological approach to the microdistribution of meiobenthic Oligochaeta. I. Phallodrilus monospermathecus (KNOLLNER) (Tubificidae) from a subtropical beach at Bermuda. In: Keegan, B. F., O'Ceidigh, P., Boaden, P. J. S. (eds.) Biology of benthic organisms. Pergamon Press, Oxford, New York, pp. 285-296

Giere, O. (1979). Studies on marine Oligochaeta from Bermuda, with emphasis on new Phallodrilus-species (Tubificidae). Cah. Biol. mar. 20: 301-314

Giere, O. (1981). The gutless marine oligochaete Phallodrilus leukodermatus. Structural studies on an aberrant tubificid associated with bacteria. Mar. Ecol. Prog. Ser. 5: 353-357

Giere, O., Pfannkuche, O. (1981). Ecology and biology of marine Oligochaeta. A review. Oceanogr. mar. Biol. A. Rev. 20: 173-308

Gocke, K., Dawson, R., Liebezeit, G. (1981). Availability of dissolved free glucose to heterotrophic microorganisms. Mar. Biol. 62: 209-216

Grasshoff, K. (ed.) (1976). Methods of seawater analysis, Verlag Chemie, Weinheim

Henrichs, S. M., Farrington, J. W. (1979). Amino acids in interstitial waters of marine sediments. Nature, Lond. 279: 319-322

Hoffmann, K. H. (1978). Anpassungen im Energiestoffwechsel von Tubifex tubifex an eine fakultativ anaerobe Lebensweise. In: Heller, H. (ed.) Verh. Ges. Okol., 7. Jahresversamml. Kiel 1977, Goltze, Göttingen, pp. 185-189

Jamieson, B. G. M. (1977). Marine meiobenthic Oligochaeta from Heron and Wistari Reefs (Great Barrier Reef) of the genera Clitellio, Limnodriloides and Phallodrilus (Tubificidae) and Grania (Enchytraeidae). Zool. J. Linn. Soc. $61:$ 329-350

Jergensen, B. B., Fenchel, T. (1974). The sulfur cycle of a marine sediment model system. Mar. Biol. 24: 189-201

Jørgensen, C. B. (1976). August Pütter, August Krogh, and the modern ideas on the use of dissolved organic matter in aquatic environments. Biol. Rev. 51: 291-328

Jørgensen, N. O. G. (1979). Uptake of L-Valine and other amino acids by the polychaete Nereis virens. Mar. Biol. 52: $45-52$

Jørgensen, N. O. G., Kristensen, E. (1980a). Uptake of amino acids by three species of Nereis (Annelida: Polychaeta). I. Transport kinetics and net uptake from natural concentrations. Mar. Ecol. Prog. Ser. 3: 329-340

Jørgensen, N. O. G., Kristensen, E. (1980b). Uptake of amino acids by three species of Nereis (Annelida: Polychaeta). II. Effects of anaerobiosis. Mar. Ecol. Prog. Ser. 3: 341-346

Jørgensen, N. O. G., Lindroth, P., Mopper, K. (1981). Extraction and distribution of free amino acids and ammonium in sediment interstitial waters from the Limfjord, Denmark. Oceanol. Acta 4: 465-474

Jørgensen, N. O. G., Mopper, K., Lindroth, P. (1980). Occurrence, origin, and assimilation of free amino acids in an estuarine environment. Ophelia 1 (Suppl.): 179-192

Johnson, K. M., Sieburth, J. McN. (1977). Dissolved carbohydrates in seawater. I. A precise spectro-photometric analysis for monosaccharides. Mar. Chem. 5: 1-13

Liebezeit, G. (1980). Aminosäuren und Zucker im marinen Milieu - neuere analytische Methoden und ihre Anwendung. Rep. SFB 95, Univ. Kiel 53: 1-195

Liebezeit, G., Dawson, R. (1981). Isoindole derivatives of amino acids for HPLC separations. Effect of reaction $\mathrm{pH}$ and time of fluorescence yield. J. High Resol. Chromat. Chromat. Commun. 4: 354-356

Lindroth, P., Mopper, K. (1979). High performance liquid chromatographic determination of sub-picomole amounts of amino acids by precolumn fluorescence derivatisation with ophthalaldehyde. Analyt. Chem. 51: 1667-1674

Lyons, W. B., Gaudette, H. E., Hewitt, A. D. (1979). Dissolved organic matter in pore water of carbonate sediments from Bermuda. Geochim. Cosmochim. Acta 43: 433-437

Meyer-Reil, L.-A., Bölter, M., Dawson, R., Liebezeit, G., Szwerinski, H., Wolter, K. (1980). Interrelationships between microbiological and chemical parameters of sandy beach sediments, a summer aspect. Appl. environ. Microbiol. 39: 797-802

Mopper, K., Dawson, R., Liebezeit, G., Ittekkot, V. (1980). Monosaccharide spectra of natural waters. Mar. Chem. 10: $55-66$

Morris, B., Barnes, J., Brown, F., Markham, J. (1977), The Bermuda marine environment. A report of the Benmuda inshore waters investigations 1976-1977. Bermuda Biological Station spec. Publ. 15: 1-120

Nichols, J. A. (1979). A simple flotation technique for separating meiobenthic nematodes from fine-graded sediments. Trans. Am. microsc. Soc. 98: 127-130

Pfannkuche, $O$. (1980). Distribution and abundance of Tubificidae and Naididae (Oligochaeta) in a brackishwater fjord, with special reference to the $\alpha$-mesohaline zone. Netherl. J. Sea Res. 14: 78-93

Powell, E. N., Crenshaw, M. A., Rieger, R. M. (1979). Adaptation to sulfide in the meiofauna of the sulfide system. I. ${ }^{35}$ S-sulfide accumulation and the presence of a sulfide detoxification system. J, exp. mar. Biol. Ecol. 37: 57-76

Powell, E. N., Crenshaw, M. A., Rieger, R. M. (1980). Adaptations to sulfide in sulfide-system meiofauna. Endproducts of sulfide detoxification in three turbellarians and a gastrotrich. Mar. Ecol. Prog. Ser 2: 169-177

Reid, R. G. B. (1980). Aspects of the biology of a gutless species of Solemya (Bivalvia: Protobranchia). Can. J. Zool. 58: 386-393

Reid, R. G., Bernard, F. R. (1980). Gutless bivalves. Science, N. Y. 208: 609-610

Reise, K., Ax, P. (1979). A meiofaunal "thiobios" limited to the anaerobic sulfide system of marine sand does not exist. Mar Biol, 54: 225-237

Reise, K., Ax, P. (1980). Statement on the thiobios-hypothesis. Mar. Biol. 58: 31-32

Rhoads, D. C. (1974). Organism-sediment relations on the muddy sea floor. Oceanogr. mar. Biol. A. Rev. 12: 263-300

Richards, K. S., Fleming, T. P., Jamieson, B. G. M. (1982). An ultrastructural study of the distal epidermis and the occurrence of subcuticular bacteria in the gutless tubificid Phallodrilus albidus (Oligochaeta, Annelida). Aust. J. Zool.30: in press

Schöttler, U., Schroff, G. (1976). Untersuchungen zum anaeroben Glykogenabbau bei Tubifex tubifex M. J. comp. Physiol. 108: 243-254

Schreurs, W. (1978). An automated colorimetric method for the determination of dissolved organic carbon in seawater by UV destruction. Hydrobiol. Bull. 12: 137-142

Siebers, D. (1976). Absorption of neutral and basic amino acids across the body surface of two annelid species. Helgoländer wiss. Meeresunters. 28: 456- 466

Siebers, D., Bulnheim, H.-P. (1977). Salinity dependence, uptake kinetics and specificity of amino acid absorption across the body surface of the oligochaete annelid Enchytraeus albidus. Helgoländer wiss. Meeresunters. 29 473-492

Southward, E. C. (1973). The distribution of glycogen in the tissues of Siboglinum atlanticum (Pognophora). J. mar biol. Ass. U.K. 53: 665-671

Southward, A. J., Southward, E. C., Brattegard, T., Bakke, T. 
(1979). Further experiments on the value of dissolved organic matter as food for Siboglinum fiordicum (Pogonophora). J. mar. biol. Ass. U. K. 59: 133-148

Southward, A. J., Southward, E. C., Dando, P. R., Rau, G. H., Felbeck, H., Flügel, H. (1981). Bacterial symbionts and low ${ }^{13} \mathrm{C} /{ }^{12} \mathrm{C}$ ratios in tissues of Pogonophora indicate unusual nutrition and metabolism. Nature, Lond. 293: 616-620

Stempell, W. (1899). Zur Anatomie von Solenomya togata Poli. Zool. Jb. (Abt. Anat. Ontogen.) 13: 89-170

Stephens, G. C. (1975). Uptake of naturally occurring primary amines by marine annelids. Biol. Bull. mar. biol. Lab., Woods Hole 149: 397-407

Tempel, D., Westheide, W. (1980). Uptake and incorporation of dissolved amino acids by interstitial Turbellaria and Polychaeta and their dependence on temperature and salinity. Mar. Ecol. Prog. Ser. 3: 41-50

Yingst, J. Y., Rhoads, D. C. (1980). The role of bioturbation in the enhancement of bacterial growth in marine sediments In: Tenore, K. R., Coull, B. C. (eds.) Marine benthic dynamics. Carolina Press, Columbia, S. C., pp. 407-421

This paper was presented by Dr. D. Siebers, it was accepted for printing on March 18, 1982 